\title{
In Vitro Antitumor Activity of Endophytic Fungi Isolated From the Mexican Cactus Pachycereus Marginatus (DC.) Britton \& Ros
}

Jesica M. Ramírez-Villalobos

Universidad Autónoma de Nuevo León

César I. Romo-Sáenz

Universidad Autónoma de Nuevo León

Karla S. Morán Santibañez

Universidad Autónoma de Nuevo León

Patricia Tamez-Guerra

Universidad Autónoma de Nuevo León

Ramiro Quintanilla-Licea

Universidad Autónoma de Nuevo León

Alonso A. Orozco-Flores

Universidad Autónoma de Nuevo León

Ricardo Romero-Argüelles

Universidad Autónoma de Nuevo León

Reyes Tamez-Guerra

Universidad Autónoma de Nuevo León

Cristina Rodríguez-Padilla

Universidad Autónoma de Nuevo León

Ricardo Gomez-Flores ( $\sim$ rgomez60@hotmail.com )

Universidad Autónoma de Nuevo León

\section{Research Article}

Keywords: Antitumor, Endophytic fungi, Cactus, Pachycereus marginatus

Posted Date: April 27th, 2021

DOI: https://doi.org/10.21203/rs.3.rs-426788/v1

License: () (i) This work is licensed under a Creative Commons Attribution 4.0 International License. Read Full License 


\section{Abstract}

Background: Arid zone plants such as cacti are known to harbor diverse groups of endophytic fungi, which represent potential sources of new compounds with anticancer properties. In the present study we isolated, identified, and characterized Pachycereus marginatus (DC.) Britton \& Ros endophytic fungi with cytotoxic activity against murine and human tumor cell lines.

Methods: Endophytic fungi were isolated from P. marginatus stems. Methanol extracts were then obtained from fungi liquid cultures and their cytotoxic activity at concentrations ranging from $31 \mu \mathrm{g} / \mathrm{ml}$ to $250 \mu \mathrm{g} / \mathrm{ml}$ against murine L5178Y-R lymphoma, human colorectal adenocarcinoma HT-29, and human breast cancer MCF-7 was evaluated by the colorimetric 3(4, 5-dimethylthiazol-2-yl)-2, 5-diphenyltetrazolium bromide reduction assay, using the normal cells Macacus rhesus monkey epitelial kidney MA-104 and human peripheral blood mononuclear cells (PBMC) as controls. $\mathrm{IC}_{50}$ values were obtained and the selectivity index $(\mathrm{SI})$ was calculated from the $\mathrm{IC}_{50}$ ratio of cancer cells and normal cells. Furthermore, molecular identification of fungi showing cytotoxic activity was determined by the internal transcribed spacer molecular marker.

Results: The Cladosporium sp. PME-H008 strain showed significant $(P<0.01) 94.3 \%$ and $36.8 \%$ cytotoxicity against L5178Y-R and HT-29 cells, respectively. The highest SI was observed by L5178Y-R cells with 2.4 and 2.9 for MA-104 and PBMC respectively. In addition, the Metarhizium anisopliae PME-H007 strain was more effective against MCF-7 with $55.8 \%$ cytotoxicity. The lowest $\mathrm{IC}_{50}$ was obtained with the Aspergillus sp. PME-H005 strain at $95.21 \mu \mathrm{g} / \mathrm{ml}$ against the MCF-7 cell line, followed by PME-H008 strain at $101 \mu \mathrm{g} / \mathrm{ml}$ against L5178Y-R cells.

Conclusion: P. marginatus endophytic fungi showed in vitro cytotoxic activity against murine and human tumor cell lines, without affecting normal cells.

\section{Background}

Cancer represents a serious public health issue and is currently considered the second cause of death worldwide, behind cardiovascular diseases. In 2020, around 9.9 million deaths by cancer were reported in the GLOBOCAN database [1]. Although radiation, surgery, immunological, hormone, and gene protocols are available, chemotherapy remains the most common method for cancer treatment [2]. However, the emergence of cancer cells resistant to antineoplastics, as well as the side effects of drugs, are major obstacles to chemotherapy success [3]. Therefore, it is essential to search for new drugs with marginal or absent side effects for the oncological patient [4].

Endophytic fungi have gained relevance in biotechnology as potential sources of new compounds with anticancer activity. Their rapid growth, culture conditions, high-cell density, easy genetic manipulation, and the possibility of scaling the production of compounds at an industrial level make them candidates for obtaining new antitumor drugs [5].

It has been proposed that the isolation of endophytic fungi, involving the selection of plants with ethnobotanical use, as well as those developing strategies for survival or growth under extreme environments [6], may lead to the discovery of endophytes that produce novel bioactive compounds. In this regard, arid zone plants such as cacti, establishes symbiotic relationships with different microorganisms, from which enzymes [7], antimicrobials [8], and anticancer compounds such as bikaverine [9] and triterpenes of the 24-homo-30-nor-cycloartane class [10] have been isolated. However, the biotechnological potential of fungi isolated from dessert plants is still limited [11].

Pachycereus marginatus, also called Stenocereus marginatus or Cereus marginatus, is a species of cactus endemic to Mexico belonging to the Cactaceae family, which is popularly known as chilayo, organ cactus or malinche [12]. In traditional medicine, it has been used for the treatment of gastrointestinal diseases [13] and diabetes [14]. Recent studies have demonstrated the antimicrobial [15] and anticancer activity of $P$. marginatus extracts in in vitro $[16,17]$ and in vivo models [18]. However, the antitumor potential of $P$. marginatus endophytic fungi has not yet been reported. Therefore, in the present 
study, they were isolated and their cytotoxic activity against murine and human tumor cell lines and normal cells was evaluated.

\section{Methods}

\section{Plant material}

P. marginatus stems were collected in General Escobedo, Nuevo León, México (100¹8'42.5"N 2547 '52.5"W) in February 2020. It was identified by M.Sci. María del Consuelo González de la Rosa, Chief of the Herbarium of Facultad de Ciencias Biológicas at Universidad Autónoma de Nuevo León, México, with voucher specimen number 025588.

\section{Isolation and morphological characterization of P. marginatus endophytic fungi}

Stems were rinsed with tap water to eliminate dust and other contaminating material, and subjected to a disinfection protocol to remove epiphytes, which consisted of washing with $70 \%$ ethanol for $1 \mathrm{~min}, 2.5 \%$ sodium hypochlorite for $3 \mathrm{~min}$, $70 \%$ ethanol for $30 \mathrm{~s}$, and two rinses with sterile distilled water and one with PBS [19]. For the isolation of endophytic fungi, the previously disinfected plant tissue was cut into small pieces. One part was placed on the surface of Petri dishes with potato dextrose agar (PDA; Difco, Detroit, MI), Sabouraud dextrose agar (SA; Difco), and agar water added with penicillinstreptomycin (60 mg/L/100 mg/L) (Life Technologies, Grand Island, NY) to inhibit microbial growth and the other section was ground in PBS in a sterile mortar. Next, $100 \mu \mathrm{l}$ of the sample were inoculated in the aforementioned culture medium by plate dispersion and the last wash with PBS was used as a negative growth control. Plates were then incubated at $20^{\circ} \mathrm{C}$ for four weeks. Morphological characterization was determined from monosporic cultures of the isolates in PDA, recording radial growth, shape, size, color, edge, and type of mycelium.

\section{Fermentation and production of methanolic extracts}

For the extraction of secondary metabolites, $1 \mathrm{~cm}^{2}$ fragments of isolate fresh cultures were individually inoculated in $250 \mathrm{ml}$ flasks with $125 \mathrm{ml}$ of potato and dextrose broth (PDB; Difco) and incubated for $30 \mathrm{~d}$ at $20^{\circ} \mathrm{C}$ and $150 \mathrm{rpm}$ (ET-4200, Tecnal Incubator, São Paulo, Brazil). After incubation, mycelium was separated by filtration and dried at $60^{\circ} \mathrm{C}$, after which it was subjected to an extraction by maceration with methanol. Solvent was then removed with a rotary evaporator (Buchi R-3000; Brinkman Instruments, Inc., Westbury, NY). Extracts were dissolved in dimethyl sulfoxide (DMSO; Sigma-Aldrich, St. Louis, $\mathrm{MO}$ ) at a final concentration of $25 \mathrm{mg} / \mathrm{ml}$ and kept at $4^{\circ} \mathrm{C}$, until use.

\section{Cell lines and culture conditions}

The cell lines used in this study were L5178Y-R (ATCC CRL-1722) (murine lymphoma), HT-29 (ATCC HTB-38) (human colorectal adenocarcinoma), MCF-7 (ATCC HTB-2) (human breast cancer), and MA-104 (ATCC® CRL-2378. $1^{\text {TM}}$ ) (monkey kidney epithelial cells). Peripheral blood mononuclear cells (PBMCs) were obtained from peripheral blood of healthy volunteer donors, using Ficoll-Paque PLUS (GE Healthcare Life Sciences, Pittsburgh, PA). Cells were maintained in RPMI1640 medium (Life Technologies) supplemented with 10\% fetal bovine serum (FBS; Life Technologies) and 1\% antibioticantifungal solution (Life Technologies), except for MCF-7 cells that were grown in Dulbecco's Modified Eagle Medium (DMEM; Life Technologies) supplemented with 10\% FBS and 1\% antibiotic-antifungal solution (Life Technologies). All cells were cultured at $37^{\circ} \mathrm{C}$ in an atmosphere of $5 \% \mathrm{CO}_{2}$.

\section{Cytotoxic activity assay}

L5178Y-R, HT-29, MCF-7, and MA-104 cell suspensions were cultured at a density of $1 \times 10^{4}$ cells/well and PBMCs at $1 \times 10^{5}$ cells/well for $24 \mathrm{~h}$ and treated with $31,62.5,125$, and $250 \mu \mathrm{g} / \mathrm{ml}$ of methanol extracts for $48 \mathrm{~h}$ at $37^{\circ} \mathrm{C}$ in $5 \% \mathrm{CO}_{2}$.

Cytotoxicity was evaluated by the colorimetric 3-[4,5-dimethylthiazol-2-yl]-2,5-diphenyltetrazoliumbromide (MTT; Affymetrix, Cleveland, OH USA) reduction assay by adding $15 \mu \mathrm{L}$ of MTT $\left(0.5 \mathrm{mg} / \mathrm{ml}\right.$ final concentration) and incubating at $37^{\circ} \mathrm{C}$ for additional $4 \mathrm{~h}$. Formazan crystals were then dissolved with DMSO and optical densities (OD) were measured at $570 \mathrm{~nm}$ in a 
MULTISKAN GO microplate reader (Thermo Fisher Scientific, Waltham, MA). The percentage of cytotoxicity was calculated as follows: \% Cytotoxicity = 100-[(A570 in extract-treated cells/A570 in untreated cells) (100)], using $0.05 \mu \mathrm{g} / \mathrm{ml}$ vincristine sulphate (Hospira, Warwickshire, UK) as a positive control. Logarithmic scale concentrations were plotted against \% cytotoxicity to determine $\mathrm{IC}_{50}$. IC $\mathrm{I}_{50}$ values were used to obtain the selectivity index (SI), for which the IC $\mathrm{I}_{50}$ of normal cells was divided by the that of cancer cells [20].

\section{Molecular identification of P. marginatus endophytic fungi}

Genomic DNA extraction was performed from monosporic cultures, using cetyltrimethylammonium bromide (CTAB; SigmaAldrich, St. Louis, MO) [21]. Purified DNA was then subjected to a PCR with the universal markers ITS1 (5'-

TCCGTAGGTGAACCTGCGG-3') and ITS4 (5'-TCCTCCGCTTATTGATATGC-3') in a volume of $50 \mu$ l, using Ruby Taq Master mix 2X (Jena Bioscience, Jena, Germany), $100 \mathrm{ng}$ of the DNA template, and $0.25 \mu \mathrm{M}$ of each primer. The amplification program consisted of a denaturation cycle of $95^{\circ} \mathrm{C}$ for $5 \mathrm{~min}, 35$ cycles of $94^{\circ} \mathrm{C}$ for $30 \mathrm{~s}, 60^{\circ} \mathrm{C}$ for $45 \mathrm{~s}$, and $72^{\circ} \mathrm{C}$ for $90 \mathrm{~s}$, followed by a final extension of $72^{\circ} \mathrm{C}$ for 8 min [22]. The PCR product was purified by the Agarose Gel Extraction kit (Jena Bioscience). Next, the product was sequenced with the ABI PRISM 310 TM Genetic Analyzer sequencer at the Synthesis and Sequencing Unit of the Institute of Biotechnology (IBT) of the UNAM, in Cuernavaca Morelos. Sequence analysis was performed using the NCBI BLAST nucleotide database.

\section{Statistical analysis}

Cytotoxicity results were expressed as mean \pm SEM of three replicates per treatment from three independent experiments. Level of significance was evaluated by the Dunnett's $t$ test. $I_{50}$ values were reported with $\pm 95 \%$ confidence intervals (95\% $\mathrm{Cl})$. Statistical analyzes were performed using the Graph Pad Prism 7 program.

\section{Results}

\section{Isolation of P. marginatus endophytic fungi}

We isolated 10 filamentous fungi from $P$. marginatus stems. Isolates were morphologically characterized, mostly showing circular shape, filamentous edge, and flat mycelium. Radial growth at $3 \mathrm{~d}$ and $7 \mathrm{~d}$ was from $5.1 \mathrm{~mm}$ to $8.5 \mathrm{~mm}$ and $9.9 \mathrm{~mm}$ to $22.6 \mathrm{~mm}$, respectively. Isolates first fermented in PDB, after which biomass methanol extraction was performed, obtaining yields ranging from $4.4-20.2 \%$.

\section{Cytotoxic activity of methanol extracts from P. marginatus endophytic fungi}

Fungi methanol extracts were evaluated at concentrations ranging from $31 \mu \mathrm{g} / \mathrm{ml}$ to $250 \mu \mathrm{g} / \mathrm{ml}$ against tumor cell lines (L5178Y-R, HT-29, and MCF-7) and normal cells (MA-104 and PBMC). Five filamentous fungi showed cytotoxic effect against tumor cell lines (Fig. 1). Extracts were effective against L5178Y-R tumor cells, whereas the least susceptible cells were HT-29. The highest percentages of cytotoxicity were obtained at a concentration of $250 \mu \mathrm{g} / \mathrm{ml}$. In this regard, PMEH008 extract caused the highest cytotoxicity against L5178Y-R and HT-29 tumor cell lines with $96.6 \%(P<0.01)$ and $42.5 \%$ $(P<0.05)$ respectively. Furthermore, the PME-H007 extract caused the highest cytotoxic activity $(P<0.01)$ against MCF-7 cells with $55.8 \%$. Regarding $\mathrm{IC}_{50}$, the PME-H005 extract showed the lowest values with $95.21 \mu \mathrm{g} / \mathrm{ml}$ for the MCF7 cell line, followed by PME-H008 with $101 \mu \mathrm{g} / \mathrm{ml}$ for L5178Y-R cells, whereas for the HT-29 cell line, the extracts showed an IC S0 higher than $291 \mu \mathrm{g} / \mathrm{ml}$. Furthermore, MA-104 cell line was more susceptible compared with PBMC, being PME-H001 with IC 50 of $437.7 \mu \mathrm{g} / \mathrm{ml}$ for the MA-104 cell line and PME-H002 with $409.8 \mu \mathrm{g} / \mathrm{ml}$ for PBMC the extracts that showed the lowest cytotoxicity. In contrast, the extract that showed the highest SI against L5178Y-R tumor cells was PME-H008 with values of 2.4 and 2.9, compared with MA-104 and PBMC respectively. For the MCF-7 cell line, we obtained an SI of 2.7 with the PMEH005 extract, compared with PBMC, and HT-29 showed values lower than 1.2 (Table 1).

\section{Molecular identification of P. marginatus endophytic fungi with antitumor activity}


We performed molecular identification of endophytic fungi that showed cytotoxic activity against tumor cell lines L5178Y-R, HT-29, and MCF-7 (Table 2). The amplified regions (ITS1-ITS4) were sequenced, and manually reviewed and analyzed using the Blast tool for fungi identification. The isolates PME-H001 and PME-H002 were identified as Penicillium citricum with 99.6\% and $99.2 \%$ homology respectively. PME-H005 and PME-H008 were only identified up to gender with $99 \%$ and $97.4 \%$, whereas PME-H007 was identified as Metarhizium anisopliae with 98.9\% homology.

\section{Discussion}

Endophytic fungi represent an important source of compounds with biological activity, such as phenolic acids, alkaloids, quinones, steroids, saponins, tannins, and terpenoids, which increases their potential in the identification of new compounds with antidiabetic, anti-inflammatory, antiviral, immunosuppressive, anti-arthritis, anti-oxidant, anti-microbial, and anti-cancer effects [23]. However, only less than $16 \%$ of the fungal species described have been cultured and studied and less than $5 \%$ of the total fungal species that have been characterized represent an important source of bioactive metabolites [24]. The distribution of certain populations of endophytic fungi is restricted to a species or family of plants, as well as to the genotype of the species, thus the presence of a specific population of fungi may determine the production of various secondary metabolites [25]. Therefore, due to the vast number of plant species in the world, different strategies have been devised to select the plants from which to isolate endophytes with biological activity, including the use of plants that have been exploited for human use in traditional medicine [26], as well as those with special strategies for their survival or that grow in extreme environments [6]. Plants that inhabit extreme environments, such as arid zones, are associated with endophytic fungi since they improve their performance and resistance against biotic and abiotic factors through the production of bioactive compounds [27]. However, the biotechnological potential of fungi isolated from this type of environment is still limited [11]. Therefore, this study reports for the first time the cytotoxic activity of endophytic fungi isolated from $P$. marginatus, a species of cactus endemic to Mexico, previously reported with anticancer activity [16-18]. In the present study, we isolated Penicillium, Aspergillus, and Cladosporium genera, which have been commonly isolated from plants that inhabit dry environments, such as cacti [19,28, 29], whereas Metarhizium has been reported as a natural endophyte of legumes [30], conifers [31], herbs, and wildflowers [32]. We then report for the first time the isolation of Metarhizium as an endophyte of cacti.

Currently, anticancer resistance is a serious problem in oncology as in the case of breast cancer [33], colon cancer [34], and Non-Hodgkin lymphoma [35]. Therefore, it is essential to search and identify new compounds with antitumor activity, for which cancer cells are not resistant [36]. Various endophytic fungi have shown anti-cancer effect against hepatoma (HepG2), lung cancer (A-549), colorectal cancer (HCT-116, HT-29), breast cancer (MCF7), ovarian cancer (SKVO3), leukemia (HL-60), carcinoma (KB), cervical cancer (Hela), and lymphoma (L5178Y) [4].

The isolated strains of $P$. citrinum PME-H001 and PME-H002, showed differential cytotoxic activity, which is consistent with other studies evidencing that the medicinal properties of endophytic fungi vary, despite they belong to the same genus and are isolated from the same host [37]. On the other hand, the anticancer activity of this species has been reported against different tumor cell lines such as A549, Hela, HepG2, L5178Y, MOLT-4, MCF-7, BT-474, and MDA-MB-231, identifying different compounds responsible for the activity, such as penicillocitrin $A$, citriquinochroman, citrinin, scalusamide $A$, perinadine $A$, pencitrin, and pencitrinol [37-41].

Fungi of the genus Aspergillus are considered an important source of bioactive compounds with anticancer activity, among which are alkaloids, pyrones, polyketides, lactones, sterols, xanthones, anthraquinones, terpenes, peptides, depsipeptides, cyclic peptides, cytochalasins, enzymes, and proteins. They have been evaluated in different tumor cell lines such as MCF7, HL-60, K-562, A549, MOLT-4 and HEP-G2 [42]. Furthermore, the potential of M. anisopliae to produce anti-cancer compounds such as taxol with yields of $846.1 \mu \mathrm{g} / \mathrm{L}$ in liquid medium has been previously demonstrated by others [31] and destruxin B with $\mathrm{IC}_{50}$ values of $4.9 \mu \mathrm{M}$ in A549 lung cancer cells [43]. 
Cladosporium sp. methanol extract caused the highest toxicity against MCF-7 cells, which agrees with a study reported by Raj et al. [44] showing the activity of taxol obtained from C. oxysporum extracts against the T47D breast cancer cell line, with an $\mathrm{IC}_{50}$ value of $2.5 \mu \mathrm{M}$, after $24 \mathrm{~h}$ of incubation.

Most anti-cancer drugs do not differentiate between tumor and normal cells, thus researchers investigate for new drugs that are selective for cancer cells, with minimal effects for other cells [5]. However, some endophytic fungal extracts such as Acremonium sp. and Pestalotiopsis suffocata are toxic against PBMCs with $\mathrm{IC}_{50}$ values of 13.4 and $12.2 \mu \mathrm{g} / \mathrm{ml}$ [45].

Endophytic fungi may play an important role in providing chemotherapeutic compounds with high specificity and minimal side effects. Therefore, the search for endophytic fungi from different habitats may provide an excellent avenue to discover new drugs and their application in the medical area, for the control of different human diseases.

\section{Conclusions}

Evaluation of $P$. marginatus endophytic fungi methanol extracts have revealed their potential as producers of bioactive compounds with antitumor activity, which may be used for the development of drugs for the treatment of cancer. The strain PME-H008 of Cladosporium sp. and PME-H007 from Metarhizium anisopliae have significant antitumor activity against lymphoma and breast cancer cells, which requires further investigation.

\section{Abbreviations}

PDA: potato dextrose agar; SA: Sabouraud dextrose agar; PBS: phosphate buffered saline; PDB: potato and dextrose broth; DMSO: dimethyl sulfoxide; PBMC: peripheral blood mononuclear cells; FBS: fetal bovine serum; DMEM: Dulbecco's Modified

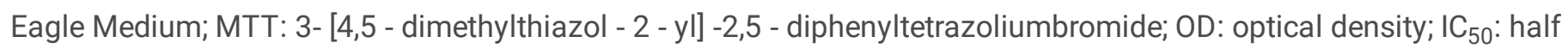
maximal inhibitory concentration; SI: selectivity index; DNA: Deoxyribonucleic acid; CTAB: cetyltrimethylammonium bromide; PCR: Polymerase chain reaction; ITS: Internal transcribed spacer region; NCBI: National Centre for Biotechnology Information; BLAST: Basic Local Alignment Search Tool; SEM: Standard error of the mean.

\section{Declarations}

\section{Experimental research and field studies on plants}

The use of plant parts in present study compiles with international, national and/or institutional guidelines. Permissions or licenses to collect the plants used in the present study were not required, since they were of free access.

\section{Ethics approval and consent to participate}

Not applicable.

\section{Consent for publication}

Not applicable.

\section{Competing interests}

The authors declare that they have no competing interests.

\section{Authors' contributions}

$\mathrm{CR}, \mathrm{KM}, \mathrm{RG}, \mathrm{PT}$ contribute to study concept and design. Plant collection, identification and isolation of endophytic fungi from plant samples were carried out by JR and RR. JR extracted the fermented broth of endophytes in the supervision of QL. JR 
carried out the anticancer experiments and results were analyzed by CR. Molecular analysis of isolated endophytes was carried out by JR and AO. RT and CRP contributed to the analysis/interpretation of data. JR wrote the manuscript. CR, KM, $R G$, edited the manuscript. All authors have read and approved the manuscript and agreed to be accountable for all aspects of the work.

\section{Funding}

This study was supported by Grant CN1235-20 from Programa de Apoyo a la Investigación Científica y Tecnológica de la UANL to RGF.

\section{Availability of data and materials}

The datasets generated and/or analyzed during the present study are available from the corresponding author on reasonable request.

\section{Author details}

${ }^{1}$ Departamento de Microbiología e Inmunología, Universidad Autónoma de Nuevo León, San Nicolás de los Garza, México C.P. 66450.

${ }^{2}$ Departamento de Química, Universidad Autónoma de Nuevo León, San Nicolás de los Garza, Mexico C.P. 66450.

\section{Acknowledgements}

We would like to thank the Laboratorio de Inmunología y Virología of Facultad de Ciencias Biológicas at Universidad Autónoma de Nuevo León for supporting this study.

\section{References}

1. International Agency for Research on Cancer Section of Cancer Surveillance. Lyon, France. 2021. http://gco.iarc.fr/. Accessed 21 march 2021.

2. Bukowski K, Kciuk M, Kontek R. Mechanisms of multidrug resistance in cancer chemotherapy. International Journal of Molecular Science 2020; 21(9):3233.

3. Li SJ, Zhang X, Wang XH, Zhao CQ. Novel natural compounds from endophytic fungi with anticancer activity. European Journal of Medicinal Chemistry. 2018; 156:316-343.

4. Rajamanikyam M, Vadlapudi V, Upadhyayula SM. Endophytic fungi as novel resources of natural therapeutics. Brazilian Archives of Biology and Technology. 2017; 60:1678-4324.

5. Kharwar RN, Mishra A, Gond SK, Stierle A, Stierle D. Anticancer compounds derived from fungal endophytes: their importance and future challenges. Natural Product Reports. 2011; 28:1208-1228.

6. Yu H, Zhang L, Li L, Zheng C, Guo L, Li W, Qin L. Recent developments and future prospects of antimicrobial metabolites produced by endophytes. Microbiological Research. 2010; 165:437-449.

7. Bezerra JDP, Santos MGS, Svedese VM, Lima DMM, Fernandes MJS, Paiva LM Souza MC M. Richness of endophytic fungi isolated from Opuntia ficus-indica Mill. (Cactaceae) and preliminary screening for enzyme production. World Journal of Microbiology and Biotechnology. 2012; 28:1989-1995.

8. Ratnaweera PB, de Silva ED, Williams DE, Andersen RJ. Antimicrobial activities of endophytic fungi obtained from the arid zone invasive plant Opuntia dillenii and the isolation of equisetin, from endophytic Fusarium sp. BMC Complementary and Alternative Medicine. 2015; 15:1-7.

9. Zhan J, Burns AM, Liu MX, Faeth SH, Gunatilaka AL. Search for cell motility and angiogenesis inhibitors with potential anticancer activity: beauvericin and other constituents of two endophytic strains of Fusarium oxysporum. Journal of 
Natural Products. 2007; 70: 227-232.

10. Li C, Wang F, Wu X, Cao S. A new 24-homo-30-nor-cycloartane triterpenoid from a Hawaiian endophytic fungal strain. Tetrahedron Letters. 2019; 61:151508.

11. Fouda AH, Hassan SED, Eid AM, Ewais EED. Biotechnological applications of fungal endophytes associated with medicinal plant Asclepias sinaica (Bioss.). Annals of Agricultural Sciences. 2015; 60(1):95-104.

12. Hernández HM, Gómez HC, Goettsch B. Checklist of Chihuahuan Desert Cactaceae. Harvard Papers in Botany. 2004; 9:51-68.

13. Hernández T, Canales M, Avila JG, Duran A, Caballero J, De Vivar AR, Lira R. Ethnobotany and antibacterial activity of some plants used in traditional medicine of Zapotitlán de las Salinas, Puebla (México). Journal of Ethnopharmacology. 2003; 88:181-188.

14. Johnson L, Strich H, Taylor A, Timmermann B, Malone D, Teufel SN, Martinez A. Use of herbal remedies by diabetic Hispanic women in the southwestern United States. Phytotherapy Research: An International Journal Devoted to Pharmacological and Toxicological Evaluation of Natural Product Derivatives. 2006; 20:250-255.

15. Moreno LS, González MPB, Herrera IM, Gutiérrez YQ, Arredondo JLM, Rodríguez RG. In vitro inhibition of Helicobacter pylori by methanolic extract of Stenocereus marginatus and Castela texana. International Journal of Medicinal Plants and Alternative Medicine. 2015; 3:10-17.

16. Hernández MHC, Gomez FR, Tamez GP, Quintanilla LR, Escamilla MÁS, Monreal CE, Rodriguez PC. Antitumor activity of Pachycereus marginatus (DC.) Britton Rose extracts against murine lymphoma L5178Y-R and skin melanoma B16F10 cells. Journal of Medicinal Plants Research. 2016; 10:635-639.

17. Quintanilla LR, Gomez FR, Samanieg EMÁ, Hernández MHC, Tamez GP, Morado CR. Cytotoxic Effect of Methanol Extracts and Partitions of Two Mexican Desert Plants against the Murine Lymphoma L5178Y-R. American Journal of Plant Sciences. 2016; 7: 1521-1530.

18. Gomez FR, Quintanilla LR, Hernández MHC, Samaniego EM, Tamez GP, Monreal CE, Rodriguez PC. Survival of lymphoma-bearing mice by Pachycereus marginatus cactus extracts and elucidation of bioactive compounds. Natural Product Communications. 2019; 14:1-6.

19. Bezerra JD, Santos MG, Barbosa RN, Svedese VM, Lima DM, Fernandes MJS, Souza MCM. Fungal endophytes from cactus Cereus jamacaru in Brazilian tropical dry forest: a first study. Symbiosis. 2013; 60:53-63.

20. Singh K, Gangrade A, Jana A, Mandal BB, Das N. Design, synthesis, characterization, and antiproliferative activity of organoplatinum compounds bearing a 1, 2, 3-triazole ring. ACS Omega. 2019; 4(1):835-841.

21. Valdés LA, Gómez A, Carballo ME, Capote-del Sol M, González I, Rohde W. Estandarización de protocolos para la extracción de ADN cromosómico en cepas de Colletotrichum gloeosporioides aislados en plantas de mango (Mangifera indica L.). La Granja: Revista de Ciencias de la Vida. 2015; 22:40-49.

22. White TJ, Bruns T, Lee S, Taylor J. (1990) Amplification and direct sequencing of fungal ribosomal RNA genes for phylogenetics. In Innis A, Gelfand DH, Sninsky JJ, and White TJ, editors. PCR Protocols: A Guide to Methods and Applications. San Diego, CA, USA: Academic Press; 1990. p. 315-322.

23. Naik BS. Potential roles for endophytic fungi in biotechnological processes: a review. Plant and Human Health. 2019; 2:327-344.

24. Bedi A, Adholeya A. Deshmukh SK. Novel anticancer compounds from endophytic fungi. Current Biotechnology. 2018; 7:168-184.

25. Jia M, Chen L, Xin HL, Zheng CJ, Rahman K, Han T, Qin LP. A friendly relationship between endophytic fungi and medicinal plants: a systematic review. Frontiers in Microbiology. 2016; 7:906.

26. De Carvalho CR, Ferreira MC, Amorim SS, da Silva FRH, De Assis JCS, Zani CL, Rosa LH. Bioactive compounds of endophytic fungi associated with medicinal plants. In: Yadav AN, Singh S, Mishra S, Gupta A, editors. Recent Advancement in White Biotechnology Through Fungi. Switzerland: Springer; 2019. p. 303-361. 
27. Ali AH, Radwan U, El-Zayat S, El-Sayed MA. Desert plant-fungal endophytic association: the beneficial aspects to their hosts. In Biological Forum-An International Journal. 2018;10: 138-145.

28. Bezerra JDP, de Azevedo JL, Souza MCM. Why study endophytic fungal community associated with cacti species?. In: De Azevedo JL, Quecine MC, editors. Diversity and Benefits of Microorganisms from the Tropics. Switzerland: Springer; 2017. p. 21-35.

29. Santos MDS, Bezerra JDP, Svedese VM, Sousa MA, da Silva DCV, Maciel MDHC, de Souza CM. Screening of endophytic fungi from cactus of the Brazilian tropical dry forest according to their L-asparaginase activity. Sydowia. 2015; 67:147156.

30. Khan AL, Hamayun M, Khan SA, Kang SM, Shinwari ZK, Kamran M, Lee IJ. Pure culture of Metarhizium anisopliae LHL07 reprograms soybean to higher growth and mitigates salt stress. World Journal of Microbiology and Biotechnology. 2012; 28:1483-1494.

31. Liu K, Ding X, Deng B, Chen W. Isolation and characterization of endophytic taxol-producing fungi from Taxus chinensis. Journal of Industrial Microbiology and Biotechnology. 2009; 36:1171.

32. Wyrebek M, Huber C, Sasan RK, Bidochka MJ. Three sympatrically occurring species of Metarhizium show plant rhizosphere specificity. Microbiology. 2011; 157: 2904-2911.

33. Fulfager A, Yadav KS. Understanding the implications of co-delivering therapeutic agents in a nanocarrier to combat multidrug resistance (MDR) in breast cancer. Journal of Drug Delivery Science and Technology. 2021; 62:102405.

34. Zhou Y, Zhang J, Wang K, Han W, Wang X, Gao M, Yang DH. Quercetin overcomes colon cancer cells resistance to chemotherapy by inhibiting solute carrier family 1, member 5 transporter. European Journal of Pharmacology. 2020; 881:173185.

35. Klener P, Klanova M. Drug resistance in non-Hodgkin lymphomas. International Journal of Molecular Sciences. 20201; 21:2081.

36. Falzone L, Salomone S, Libra M. Evolution of cancer pharmacological treatments at the turn of the third millennium. Frontiers in Pharmacology. 2018; 9:1300.

37. Danagoudar A, Joshi CG, Ravi SK, Kumar HGR, Ramesh BN. Antioxidant and cytotoxic potential of endophytic fungi isolated from medicinal plant Tragia involucrata L. Pharmacognosy Research. 2018; 10:188-194.

38. Li X, Zhang L, Liu Y, Guo Z. Deng Z, Chen J, Zou K. A new metabolite from the endophytic fungus Penicillium citrinum. Natural Product Communications. 2013; 8:587-588.

39. El-Neketi M, Ebrahim W, Lin W, Gedara S, Badria F, Saad HEA, Proksch P. Alkaloids and polyketides from Penicillium citrinum, an endophyte isolated from the Moroccan plant Ceratonia siliqua. Journal of natural products. 2013; 76:10991104.

40. Mady M, Wael W, Abdou R, Haggag E, El Sayed K. Breast cancer migration and proliferation inhibitory and antibiotic secondary metabolites from the Egyptian olive tree endophytic fungus Penicillium citrinum. Journal of Advanced Pharmacy Research. 2017; 1: 160-170.

41. Hu Y, Zhang J, Liu D, Guo J, Liu T, Xin Z. Pencitrin and pencitrinol, two new citrinin derivatives from an endophytic fungus Penicillium citrinum salicorn 46. Phytochemistry Letters. 2017; 22:229-234.

42. Nadumane VK, Venkatachalam P, Gajaraj B. Aspergillus applications in cancer research. In Rastegari AA, Yadav AN, Yadav N, editors. New and Future Developments in Microbial Biotechnology and Bioengineering. United Kindom: Elsevier; 2016. p. 243-255.

43. Wu CC, Chen TH, Liu BL, Wu LC, Chen YC, Tzeng YM, Hsu SL. Destruxin B isolated from entomopathogenic fungus Metarhizium anisopliae induces apoptosis via a $\mathrm{Bcl}-2$ family-dependent mitochondrial pathway in human nonsmall cell lung cancer cells. Evidence-Based Complementary and Alternative Medicine. 2013;

https://doi.org/10.1155/2013/548929. 
44. Raj KG, Sambantham S, Manikanadan R, Arulvasu C, Pandi M. Fungal taxol extracted from Cladosporium oxysporum induces apoptosis in T47D human breast cancer cell line. Asian Pacific Journal of Cancer Prevention. 2014; 15:66276632.

45. Kumar DSS, Cheung HY, Lau CS, Chen F, Hyde KD. In vitro studies of endophytic fungi from Tripterygium wilfordii with anti-proliferative activity on human peripheral blood mononuclear cells. Journal of Ethnopharmacology. 2004; 94:295300.

\section{Tables}

Table 1. $I C_{50}$ values $(\mu \mathrm{g} / \mathrm{ml})$ and SI of tumor cell lines treated with methanol extracts, compared with MA-104 and PBMC cells.

\begin{tabular}{|lllllllll|}
\hline Isolate code & L5178Y-R & \multicolumn{2}{c}{ HT-29 } & & MCF-7 & \multicolumn{2}{c|}{ MA-104 } & PBMC \\
\cline { 2 - 9 } & $I_{50}$ & SI* & $I_{50}$ & SI $_{5}$ & $I_{50}$ & SI $^{*}$ & $I_{50}$ & $I_{50}$ \\
\hline PME-H001 & $269.4 \pm 1.4$ & $1.6 / 1$ & $348.1 \pm 1.1$ & $1.2 / 0.8$ & $1387 \pm 0.7$ & $0.3 / 0.2$ & $437.7 \pm 0.8$ & $295.4 \pm 1.2$ \\
\hline PME-H002 & $266.5 \pm 1.4$ & $1.1 / 1.5$ & $402.5 \pm 1$ & $0.7 / 1$ & $1244 \pm 0.6$ & $0.2 / 0.3$ & $295.4 \pm 1.4$ & $409.8 \pm 1.2$ \\
\hline PME-H005 & $166.2 \pm 1.8$ & $0.7 / 1.5$ & $291.6 \pm 1.2$ & $0.4 / 0.9$ & $95.21 \pm 1$ & $1.2 / 2.77$ & $123.5 \pm 1.3$ & $264 \pm 1.5$ \\
\hline PME-H007 & $132.9 \pm 1.5$ & $1.8 / 0.7$ & $291.7 \pm 1.3$ & $0.8 / 0.7$ & $114.7 \pm 1.3$ & $2.1 / 1.8$ & $245.9 \pm 1.9$ & $215.8 \pm 1.6$ \\
\hline PME-H008 & $101 \pm 1.5$ & $2.4 / 2.9$ & $301.1 \pm 1.2$ & $0.8 / 0.9$ & $337.5 \pm 1.3$ & $0.7 / 0.8$ & $250.2 \pm 1.2$ & $298.8 \pm 1.4$ \\
\hline
\end{tabular}

$* S I=M A-104 / P B M C$.

Table 2. Morphological characterization and molecular identification of $P$. marginatus endophytic fungi with cytotoxic activity.

\begin{tabular}{|c|c|c|c|c|c|c|c|c|c|}
\hline \multirow{2}{*}{$\begin{array}{l}\text { Isolate } \\
\text { code }\end{array}$} & \multicolumn{2}{|c|}{$\begin{array}{l}\text { Radial } \\
\text { growth } \\
(\mathrm{mm})\end{array}$} & \multirow[t]{2}{*}{ Shape } & \multirow[t]{2}{*}{ Edge } & \multirow[t]{2}{*}{ Mycelium } & \multirow{2}{*}{$\begin{array}{l}\text { Above } \\
\text { color* }\end{array}$} & \multirow{2}{*}{$\begin{array}{l}\text { Reverse } \\
\text { color* }\end{array}$} & \multicolumn{2}{|c|}{ Molecular identification } \\
\hline & $3 d$ & $7 d$ & & & & & & $\begin{array}{l}\text { Identification } \\
\text { based on the } \\
\text { sequence } \\
\text { ITS1-ITS4 }\end{array}$ & $\begin{array}{l}\text { Homology } \\
\text { percentage }\end{array}$ \\
\hline $\begin{array}{l}\text { PME- } \\
\text { H001 }\end{array}$ & 7.3 & 9.9 & Circular & Filamentous & Flat & \# 838B83 & $\begin{array}{l}\text { \#F0E68C/ } \\
\text { EEF3E2 }\end{array}$ & $\begin{array}{l}\text { Penicillium } \\
\text { citrinum }\end{array}$ & $99.6 \%$ \\
\hline $\begin{array}{l}\text { PME- } \\
\text { H002 }\end{array}$ & 8.5 & 17.5 & Circular & Filamentous & Flat & \#838В83 & $\begin{array}{l}\text { \#F0E68C/ } \\
\text { EEF3E2 }\end{array}$ & $\begin{array}{l}\text { Penicillium } \\
\text { citrinum }\end{array}$ & $99.2 \%$ \\
\hline $\begin{array}{l}\text { PME- } \\
\text { H005 }\end{array}$ & 8.1 & 17.9 & Circular & Irregular & Flat & \#838В83 & $\begin{array}{l}\text { \#FFC125/ } \\
\text { FEF0C9 }\end{array}$ & $\begin{array}{l}\text { Aspergillus } \\
\text { sp. }\end{array}$ & $99 \%$ \\
\hline $\begin{array}{l}\text { PME- } \\
\text { H007 }\end{array}$ & 6.2 & 22.6 & Circular & Filamentous & Flat & $\begin{array}{l}\text { \#006400/ } \\
\text { FFFFFF }\end{array}$ & $\begin{array}{l}\text { \#CD9B10/ } \\
\text { EEDC82 }\end{array}$ & $\begin{array}{l}\text { Metarhizium } \\
\text { anisopliae }\end{array}$ & $98.9 \%$ \\
\hline $\begin{array}{l}\text { PME- } \\
\text { H008 }\end{array}$ & 5.1 & 15.2 & Circular & Entire & Flate & $\begin{array}{l}\text { \#2F4F4F } \\
\text { /EBECE4 }\end{array}$ & \#FEFEF2 & $\begin{array}{l}\text { Cladosporium } \\
\text { sp. }\end{array}$ & $97.4 \%$ \\
\hline
\end{tabular}




\section{Figures}
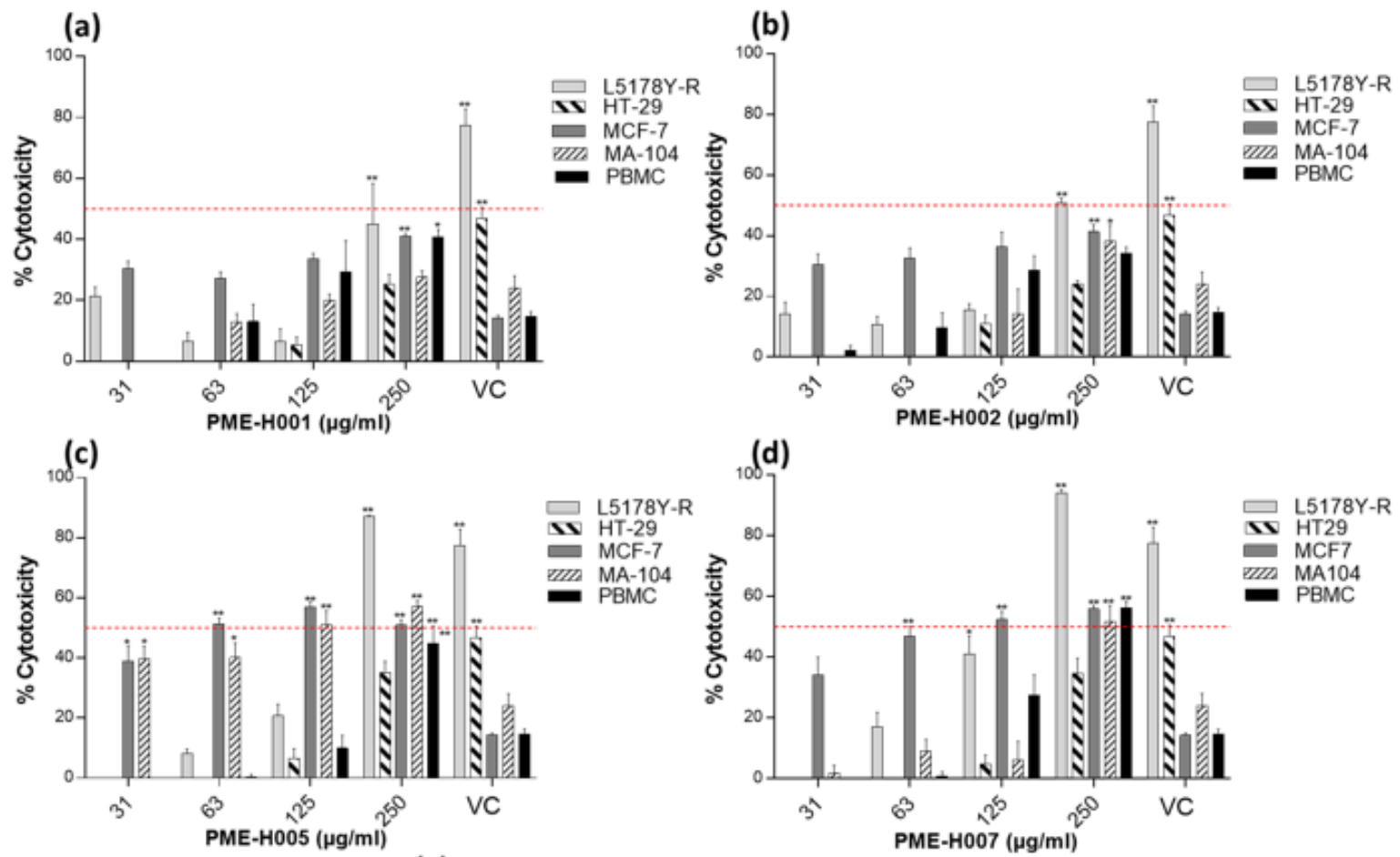

(e)

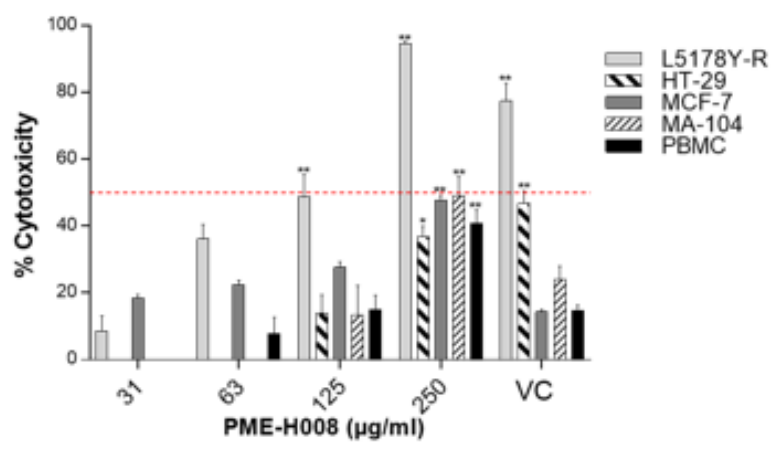

Figure 1

Cytotoxic activity of methanol extracts from P. marginatus endophytic fungi against tumor and non-tumor cells. L5178Y-R, HT-29, MCF-7, and MA-104 cells were cultured at $1 \times 104$ cells/well and PBMC at $1 \times 105$ cells/well for $24 \mathrm{~h}$ and treated with 31 $\mathrm{mg} / \mathrm{ml}$ to $250 \mu \mathrm{g} / \mathrm{ml}$ of methanol extracts for $48 \mathrm{~h}$, as detailed in the text. Cytotoxicity was evaluated by the MTT reduction assay and ODs measured at $570 \mathrm{~nm}$, using $0.05 \mu \mathrm{g} / \mathrm{ml}$ vincristine sulphate as a positive control. Dotted line represents the IC50. Data represent mean \pm SEM of triplicates from three independent experiments. ${ }^{*}, P<0.05$; $* \star P<0.01$, as compared with untreated control. OD for untreated control was $1.39 \pm 0.12$. 